\title{
ANALIZA KVALITETE VISOKOŠKOLSKIH KNJIŽNICA KROZ PRIZMU POSTUPKA REAKREDITACIJE HRVATSKIH VISOKIH UČILIŠTA
}

\author{
QUALITY ANALYSIS OF ACADEMIC LIBRARIES \\ WITHIN THE RE-ACCREDITATION PROCESS OF THE \\ CROATIAN INSTITUTIONS OF HIGHER EDUCATION
}

\author{
Aleksandra Pikić \\ Zavod za knjižničarstvo \\ Nacionalna i sveučilišna knjižnica Zagreb \\ apikic@nsk.hr
}

UDK / UDC 027.7:378.014.6(497.5)

Izvorni znanstveni rad / Original scientific paper

Prihvaćeno / Accepted: 11. 4. 2017.

\section{Sažetak}

Periodično vrednovanje visokoškolskih knjižnica u sklopu reakreditacije hrvatskih visokih učilišta započelo je ak. god. 2010./2011. Stručna povjerenstva sastavljena od profesora i studenata srodnih institucija procjenjivala su knjižnice veleučilišta, visokih škola i sveučilišnih sastavnica u kontekstu knjižnične institucionalne podrške studentskom učenju i istraživanju. Cilj ovog istraživanja bio je identificirati aspekte kvalitete pomoću kojih su visokoškolske knjižnice opisane u izvješćima povjerenstava tijekom reakreditacije te utvrditi razinu njihove kvalitete. Istraživanje je provedeno krajem 2015. godine na komentarima knjižničnih resursa visokih učilišta iz 107 izvješća stručnih povjerenstava. Tematskom analizom komentara dobivena su sljedeća područja kvalitete knjižnične usluge: 1) relevantnost tiskanog i elektroničkog knjižničnog fonda, 2) adekvatnost veličine i karakteristika fizičkog prostora, 3) jednostavnost pristupa knjižničnoj građi, elektroničkim izvorima i internetu, 4) opći dojam o kvaliteti knjižnice, 5) adekvatnost brojnosti i kompetencija osoblja, 6) adekvatnost financija te 7) korištenje knjižničnih resursa drugih ustanova. Rezultati analize stanja knjižnica pokazali su da

Vjesnik bibliotekara Hrvatske 60, 2-3(2017), 47-77

ISSN 0507-1925

(C) VBH 2017. 
su stručna povjerenstva u većoj mjeri kritizirala knjižnične resurse visokih učilišta, pri čemu su kritizirane knjižnice okvalificirane kao neadekvatna podrška za studentsko učenje $i$ istraživanje. S druge strane, stručna povjerenstva povoljno su vrednovala knjižnične resurse samo nekolicine visokih učilišta. Knjižnice tih visokih učilišta mogu ukazati na smjer kojim bi druga visoka učilišta mogla razvijati svoje knjižnične resurse $\mathrm{s}$ ciljem bolje uspješnosti svojih studenata i zaposlenika.

Ključne riječi: visokoškolske knjižnice, vrednovanje, reakreditacija visokih učilišta, kvaliteta knjižnične usluge

\section{Summary}

The periodic evaluation of the Croatian academic libraries was started within the re-accreditation of higher education institutions in Croatia during the academic year 2010/2011. The libraries of polytechnics, colleges and university constituents were assessed in the context of their support to student learning and research by the expert panels teamed up with professors and students. The aim of this study was to identify the quality aspects by which the academic libraries were assessed, and to determine the quality level of the libraries. The research was conducted in late 2015 on 107 reports with comments and remarks on the Croatian higher education institutions library resources. The thematic analysis of comments resulted with the following domains of library services quality: 1) relevance of printed and electronic library collections, 2) adequacy of size and the characteristics of library space and premises, 3) ease of access to library materials, electronic resources, and the Internet, 4) general impressions on the quality of libraries, 5) adequacy of the library staff number and their competence, 6) adequacy of finances, and 7) use of other institutions' library resources. The results showed that the expert panels had considerably criticized the quality of library resources of the re-accredited higher education institutions. The criticized libraries were often qualified as an inadequate support for the students' learning and research. On the other hand, the expert panels assessed favorably only a small number of higher education institutions libraries. However, the positive evaluation of these libraries may indicate the future direction in which other higher education institutions could develop their library resources, with the aim of improving their students' and employees' working conditions and effectiveness.

Keywords: academic libraries, evaluation, institutions of higher education re-accreditation, library service quality 


\section{Uvod}

U svjetskim okvirima visokoškolske su knjižnice dugo smatrane „srcem“ sveučilišta - središnjim mjestom visokih učilišta, prostorom učenja, istraživanja, pisanja i diskusija, no promjenama u sustavu visokog školstva, a posebno razvojem informacijsko-komunikacijskih tehnologija, te knjižnice suočene su s brojnim iskušenjima koja dovode u pitanje njihovu ulogu i organizaciju poslovanja. Razvoj informacijsko-komunikacijskih tehnologija stubokom je promijenio potrebe i navike korisnika, visokoškolske knjižnice i njihov međusobni odnos. U resursima poput World Wide Weba i interneta te pretraživačima poput Googlea pomoću kojih se može jednostavno i brzo pristupiti ogromnoj količini informacija i znanja, visokoškolske knjižnice dobivaju jaku konkurenciju na „tržištu“ informacija i znanja. Dok je korištenje interneta za pretragu potrebnih informacija počelo rasti $^{1}$, a pristup elektroničkim informacijama postaje sve važniji ${ }^{2}$, istovremeno visokoškolske knjižnice počinju bivati sve praznije. Brojni autori izvještavaju o trendu pada korištenja visokoškolskih knjižnica u tradicionalnom smislu, pada dolazaka u prostor knjižnice ${ }^{3}$, pada transakcija u referentnoj zbirci ${ }^{4}$ i pada cirkulacije građe. ${ }^{5}$ Kako je modificirala navike i potrebe korisnika, informacijsko-komunikacijska tehnologija isto je tako transformirala knjižnicu iz isključivo fizičkog mjesta s tekstnom građom u novu hibridnu knjižnicu koja pomoću različitih usluga i tehnologija nastoji integrirati različite vrste građe (tradicionalne i digitalne) kako bi korisnicima omogućila integrirani pristup svim izvorima. ${ }^{6}$ Stara paradigma knjižničarstva, koja je u središte svog interesa stavljala čuvanje tiskane građe, zamijenjena je novom paradigmom prema kojoj korisnik i njegove potrebe, $u$ prvom redu pristup informacijama, elektroničkim izvorima, građi i uslugama 24 sata dnevno, postaju fokus cjelokupnog poslovanja visokoškolskih knjižnica. Sve te promjene utjecale su i na određivanje što bi trebala biti kvalitetna knjižnica iz perspektive korisnika.

Jedan od najpopularnijih teorijskih modela kvalitete (knjižnične) usluge počiva na postulatu da upravo korisnikovo mišljenje vrijedi poslušati i da je on najbo-

\footnotetext{
1 Cullen, Rowena. Addressing the digital divide. // Online Information Review 25, 5(2001), str. 311.

2 Lincoln, Yvonna S. Insights into library services and users from qualitative research. // Library \& Information Science Research 24(2002), str. 12.

3 Thompson, Bruce; Martha Kyrillidou; Colleen Cook. On-premises library versus Google-like information gateway usage patterns : a LibQUAL $+\mathbb{B}$ study. // portal: Libraries and the Academy 7, 4(2007), str. 465.

4 Kyrillidou, Martha; Mark Young. ARL Statistics, 2003-04 : a compilation of statistics from the one hundred and twenty-three members of the Association of Research Libraries. Washington, DC : Association of Research Libraries, 2005. Str. 7-8.

5 Isto.

6 Brophy, Peter. The academic library. London: Facet Publishing, 2002. Str. 46-47.
} 
lji sudac o kvaliteti usluge koju koristi. Model nerazmjera u kvaliteti usluge općenito (engl. Service Quality Gap theory) američkih ekonomista A. Parasuramana, Valarie A. Zeithaml i Leonarda L. Berrya ${ }^{7}$ poslužio je za ishodište promišljanja kvalitete knjižnične usluge iz korisničke perspektive, odnosno za konceptualno utemeljenje instrumenta LibQUAL+TM. Taj instrument definira kvalitetu knjižnične usluge kao percepciju o smjeru i mjeri odstupanja dobivene razine usluge od one koju je korisnik očekivao, s time da se odstupanje mjeri na tri odrednice kvalitete: knjižnično osoblje, mogućnost kontrole informacija i prostor knjižnice. Odrednicom knjižnično osoblje utvrđuje se kvaliteta odnosa osoblja prema korisnicima za vrijeme isporuke usluge. Ispitanici procjenjuju razumijevanje korisničkih potreba, ljubaznost, brižnost $i$ individualiziran odnos osoblja, spremnost da osoblje trenutno pruži uslugu ili pomoć, znanje i kompetentnost osoblja, odnosno njegovu sposobnost da ulijeva povjerenje korisnicima te, također, pouzdanost osoblja, odnosno isporučivanje obećane usluge pouzdano, na vrijeme i točno. Mogućnost kontrole informacija druga je odrednica kvalitete knjižnične usluge kojom se definira adekvatnost i dostupnost fonda tiskane i elektroničke građe, mogućnost lakog pronalaženja i korištenja građe, elektroničkih izvora, ali i svih ostalih informacija bez obzira na to je li u pitanju fizički ili virtualni prostor knjižnice, a sve s ciljem samostalnog korištenja knjižnice, neovisnog od knjižničnog osoblja. Posljednja, treća odrednica kvalitete knjižnične usluge jest kvaliteta prostora knjižnice kojom se utvrđuje udobnost i privlačnost radnog prostora za učenje i proučavanje. ${ }^{8}$ Iako je namijenjen svim vrstama knjižnica, LibQUAL+TM najviše je primjenjivan $u$ istraživanju kvalitete visokoškolskih knjižnica.

\section{Kontekst poslovanja hrvatskih visokoškolskih knjižnica}

Kada razmatramo stanje hrvatskih visokoškolskih knjižnica, vidimo da su, osim globalnim promjenama, one dodatno opterećene i nepovoljnom situacijom koju karakteriziraju njihova fragmentarnost, smanjena sredstva za nabavu knjižničnih materijala te zastarjelost pravnog okvira za poslovanje. Fragmentarnost se ogleda u većem broju visokoškolskih knjižnica s jednom zaposlenom osobom te u velikom broju manjih odjelnih knjižnica koje posluju bez međusobno koordinirane nabave knjižnične građe. ${ }^{9}$ Osim toga, na fragmentarnost utječu i mnogobrojni softveri koje u svom poslovanju koriste knjižnice visokih učilišta: Aleph, Crolist Koha, Lteko, Medved, Metel i Zaki. Iako je započela testna faza izgradnje sku-

\footnotetext{
7 Parasuraman, A.; Valarie A. Zeithaml; Leonard L. Berry. A conceptual model of service quality and its implications for future research. // Journal of Marketing 49, Fall(1985), 41-50.

8 Pikić, Aleksandra. Kvaliteta knjižnične usluge u visokoškolskoj knjižnici iz korisničke perspektive : doktorski rad. Zagreb : A. Pikić, 2015. Str. 61-62.

9 Petrak, Jelka; Tatjana Aparac Jelušić. Knjižnice na hrvatskim sveučilištima : tradicije i promjene. // Vjesnik bibliotekara Hrvatske 48, 1(2005), 20-21.
} 
pnog kataloga Nacionalne i sveučilišne knjižnice u Zagrebu te knjižnica Sveučilišta u Zagrebu ${ }^{10}$, velika većina hrvatskih visokoškolskih knjižnica nije međusobno povezana jedinstvenim skupnim katalogom, što njihovim korisnicima, članovima akademske zajednice, otežava pretragu građe. Uz to što je fragmentarno, može se reći da je poslovanje hrvatskih visokoškolskih knjižnica i neujednačeno budući da samo neke od njih naprimjer nude edukacije svojim korisnicima, imaju repozitorije ili svojim korisnicima nude dodatne elektroničke izvore osim onih nabavljenih nacionalnom konzorcijskom pretplatom.

Pored toga, visokoškolske knjižnice suočavaju se sa sve većim rezanjem financijskih sredstava, pa često nemaju dovoljno sredstava za nabavu građe, e-izvora i opreme, razvijanje usluga ili cjeloživotno obrazovanje knjižničara. Sve navedeno predstavlja otežavajuće okolnosti koje priječe stvaranje učinkovite koordinacije, racionalno poslovanje pri nabavi i obradi građe te razvoj mreže visokoškolskih knjižnica općenito, što bi u konačnici omogućilo bolju iskoristivost postojećih knjižničnih fondova i usluga, a korisnicima osiguralo kvalitetniju uslugu. ${ }^{11} \mathrm{Ra}-$ zvoj hrvatskih visokoškolskih knjižnica dodatno otežava zastarjelost njihova pravnog okvira. U ovom trenutku zastarjela su dva bitna pravna akta koji reguliraju poslovanje visokoškolskih knjižnica - Zakon o knjižnicama ${ }^{12}$ i Standardi za visokoškolske knjižnice. ${ }^{13}$

Neujednačenost i nepovezanost $u$ poslovanju te zastarjelost $\mathrm{i} / \mathrm{ili}$ nedorečenost zakonskog okvira otežavaju utvrđivanje kriterija za vrednovanje hrvatskih visokoškolskih knjižnica. Unatoč svim otegotnim okolnostima, utvrđivanje kvalitete hrvatskih visokoškolskih knjižnica započeto je sustavom praćenja kvalitete njihovih osnivača, visokih učilišta, što je jedna od zadaća koju je Republika Hrvatska preuzela implementacijom bolonjskog procesa u svoj sustav visokog obrazovanja.

\section{Vrednovanje knjižničnih resursa u postupku reakreditacije hrvat- skih visokih učilišta}

Svaka država potpisnica Bolonjske deklaracije, pa tako i Republika Hrvatska, obvezala se zakonski urediti te redovito provoditi praćenje kvalitete institucionalnih resursa i studijskih programa visokih učilišta. Agencija za znanost

10 Skupni katalog Nacionalne i sveučilišne knjižnice i Sveučilišta u Zagrebu. [citirano: 2017-0515]. Dostupno na http://skupnikatalog.nsk.hr/.

11 Petrak, Jelka; Tatjana Aparac-Jelušić. Nav. dj., str. 26-27.

12 Zakon o knjižnicama. // Narodne novine 105, 1616(1997). [citirano: 2017-05-05]. Dostupno na http://narodne-novine.nn.hr/clanci/sluzbeni/1997_10_105_1616.html.

13 Standardi za visokoškolske knjižnice u Republici Hrvatskoj. // Glasnik Ministarstva prosvjete i kulture Republike Hrvatske 1, 3/4(1991), 19-21. 
i visoko obrazovanje (u nastavku teksta: AZVO) ustanova je ovlaštena za provedbu vanjskog vrednovanja, odnosno provjere kvalitete visokih učilišta te njihovih studijskih programa u Republici Hrvatskoj. Vanjsko vrednovanje ima za cilj izdavanje, odnosno uskraćivanje suglasnosti za osnivanje visokih učilišta i njihovih studijskih programa, kao i izdavanje, odnosno uskraćivanje dopusnice za obavljanje djelatnosti visokog obrazovanja. Bolonjski proces ${ }^{14}$ visokoškolskim je knjižnicama osigurao mjesto u sustavu vrednovanja. U referentnom dokumentu za vrednovanje visokih učilišta „Standardi i smjernice za osiguranje kvalitete u europskom prostoru visokog obrazovanja“" ${ }^{15}$ knjižnice se spominju u kontekstu obrazovnih resursa i pomoći studentima koje visoko učilište mora osigurati, čime su one prepoznate kao važan pokazatelj kvalitete institucionalne podrške učenju, a onda i studentskog uspjeha.

Iako na samom početku visoka učilišta u osnivanju moraju (među ostalim) predati dokumentaciju o prostornim uvjetima i opremi koja sadržava podatke o njihovim knjižnicama, knjižnični resursi visokih učilišta ocjenjuju se tek u postupku reakreditacije visokog učilišta. U tom postupku visoka učilišta moraju dokazati da ona i njihovi studijski programi ispunjavaju nužne unaprijed postavljene uvjete, kriterije i standarde kako bi obavljala djelatnost visokog obrazovanja. Predviđeno je da visoka učilišta prolaze proces reakreditacije svakih pet godina, a izvješća i preporuke vezane uz postupak reakreditacije dostupni su na mrežnim stranicama AZVO- ${ }^{16}$.

Vrednovanje knjižnice u postupku reakreditacije visokog učilišta započinje izradom dokumenta „samoanalize“ koji je predmetno visoko učilište obvezno izraditi prema službenim uputama AZVO-a za visoka učilišta u sastavu sveučilišta ${ }^{17}$, odnosno uputama za veleučilišta i visoke škole. ${ }^{18} \mathrm{U}$ tom dokumentu visoko učilište mora prikazati stanje i ocijeniti kvalitetu svojih knjižničnih resursa. Stanje opisuje ključnim elementima knjižničnog poslovanja: knjižničnim fon-

14 Bolonjski proces naziv je za reformu visokog obrazovanja u zemljama Europske unije koja je imala za cilj transformirati razdijeljeni europski prostor visokog obrazovanja u usporedivi, kompatibilni i koherentni sustav visokog obrazovanja. Bolonjski proces temelji se na deklaraciji Europski prostor visokoga obrazovanja, koja se danas popularno naziva Bolonjskom deklaracijom.

15 Standardi i smjernice za osiguranje kvalitete $\mathrm{u}$ europskom prostoru visokog obrazovanja. [citirano: 2017-05-05]. Dostupno na http://www.enqa.eu/indirme/esg/ESG\%20in\%20Croatian by\%20ASHE.pdf.

16 Akreditacijske preporuke [citirano: 2017-05-05]. Dostupno na https://www.azvo.hr/hr/vrednovanja/postupci-vrednovanja-u-visokom-obrazovanju/akreditacijske-preporuke.

17 Upute za izradu samoanalize visokih učilišta u sastavu sveučilišta. [citirano: 2017-05-05]. Dostupno na https://www.azvo.hr/images/stories/vrednovanja/reakreditacija_vu/Upute\%20 za\%20sastavljanje\%20samoanalize-sveu\%C4\%8Dili\%C5\%A1ta-2013.doc.

18 Upute za izradu samoanalize veleučilišta i visokih škola. [citirano: 2017-05-05]. Dostupno na https://www.azvo.hr/images/stories/vrednovanja/reakreditacija_vu/Upute\%20za\%20sastavljanje\%20samoanalize-visoke\%20\%C5\%A1kole-veleu\%C4\%8Dili\%C5\%A1ta\%202013.doc . 
dom, prostorom knjižnice, financijskim sredstvima za nabavu knjižnične građe, korištenjem resursa te osobljem knjižnice. Samoanalizu dobiva na uvid stručno povjerenstvo za reakreditaciju visokog učilišta koje je imenovano od strane AZVO-a. Članovi stručnog povjerenstva odabrani su strani i domaći stručnjaci iz znanstvenog područja djelovanja reakreditiranog visokog učilišta te studenti srodnih fakulteta. Kako bi se što bolje upoznala sa stanjem i djelovanjem visokog učilišta i njihovih knjižnica, stručna povjerenstva obvezna su posjetiti njihove prostore te razgovarati sa zaposlenicima i studentima. Slijedom toga, analiziraju stanje knjižnica visokog učilišta: a) uvidom u opis knjižničnih resursa u samoanalizi reakreditiranog visokog učilišta, b) posjetom prostoru knjižnice i razgovorom s knjižničnim osoblje te c) razgovorom sa studentima o njihovu iskustvu korištenja knjižnicom. Na samom kraju svog dijela obveza u postupku reakreditacije, stručna povjerenstva pišu izvješće o stanju knjižničnih resursa uzimajući u obzir samoanalizu, dojmove koje su stekli posjetom visokom učilištu, ali i svojim prijašnjim iskustvima korištenja visokoškolskim knjižnicama.

Za razliku od dosadašnjih istraživanja koja su imala za cilj vrednovanje pojedinačnih knjižnica poput Čuić ${ }^{19}$, Petr ${ }^{20}$, Petr Balog i Plašćak ${ }^{21}$, Pikić ${ }^{22}$, Radičević $^{23}$ i Udiljak Bugarinovski ${ }^{24}$ ili manjeg broja sveučilišnih knjižnica ili knjižnica sveučilišnih sastavnica poput Dukić, Hasenay i Mokriš Marendić25, Petr Balog, Dragija Ivanović i Feldvari ${ }^{26}$, Badurina, Dragija Ivanović i Krtalićc ${ }^{27}$, Morić Fi-

\footnotetext{
19 Čuić, Blaženka. Balanced scorecard kao pomagalo za vrednovanje knjižnice : primjer Knjižnice Filozofskog fakulteta u Osijeku. // Vjesnik bibliotekara Hrvatske 55, 1(2012), 45-64.

20 Petr, Kornelija. Uspješnost poslovanja knjižnice Pedagoškog fakulteta u Osijeku : zadovoljstvo korisnika knjižnicom i njezinim uslugama. // Vjesnik bibliotekara Hrvatske 43, 4(2000), 80-90.

21 Petr Balog, Kornelija; Bernardica Plašćak. Customer satisfaction at the Faculty of Philosophy Library in Osijek, Croatia. // Performance Measurement and Metrics 13, 2(2012), 74-91.

22 Pikić, Aleksandra. Nav. dj.

23 Radičević, Vesna. Samovrednovanje visokoškolske knjižnice - na primjeru Knjižnice Filozofskog fakulteta u Osijeku. //Knjižničarstvo 17, 1(2013), 83-98. [citirano: 2017-01-12]. Dostupno na http://www.knjiznicarstvo.com.hr/wp-content/uploads/2013/06/210_Radicevic_2013_1. pdf.

24 Udiljak Bugarinovski, Zrinka. Benchmarking u funkciji unaprjeđenja marketinga u visokoškolskim knjižnicama : specijalistički poslijediplomski rad. Zagreb: Z. Udiljak Bugarinovski, 2011.

25 Dukić, Gordana; Sanda Hasenay; Svjetlana Mokriš Marendić. Analiza zadovoljstva korisnika/ studenata u knjižnicama Prehrambeno-tehnološkog i Pravnog fakulteta te u Gradskoj i sveučilišnoj knjižnici Osijek. // Vjesnik bibliotekara Hrvatske 52, 1-4(2010), 172-187.

26 Petr Balog, Kornelija; Martina Dragija Ivanović; Kristina Feldvari. Percepcija kvalitete 'iznutra' : razgovori s ravnateljima narodnih i voditeljima visokoškolskih knjižnica. // Vjesnik bibliotekara Hrvatske 53, 3-4(2010), 1-24.

27 Badurina, Boris; Martina Dragija Ivanović; Maja Krtalić. Vrednovanje knjižničnih službi i usluga akademskih i narodnih knjižnica. // Vjesnik bibliotekara Hrvatske 53, 1(2010), 47-63.
} 
lipović i Dragija Ivanoviće 28 , ovim istraživanjem željelo se dobiti uvid u stanje većine hrvatskih visokoškolskih knjižnica, a posebno dosad neispitanih knjižnica veleučilišta i visokih škola.

\section{Istraživanje}

\subsection{Cilj istraživanja i istraživački problemi}

U radu ćemo se fokusirati na analizu komentara knjižničnih resursa kako su ih vidjeli članovi stručnih povjerenstava prvog ciklusa reakreditacije hrvatskih visokih učilišta. Prvi ciklus reakreditacije započet je ak. god. 2010./2011., s planiranim završetkom u ak. god. 2015./16. Cilj ovog istraživanja bio je identificirati aspekte kvalitete pomoću kojih su članovi povjerenstava za reakreditaciju visokih učilišta vrednovali visokoškolske knjižnice. Slijedno tomu, željeli smo odgovoriti na dva istraživačka pitanja: a) kojim su temama stručna povjerenstva opisala stanje visokoškolskih knjižnica i b) kako su ih vrednovala.

\subsection{Metoda istraživanja}

Za potrebe ovog istraživanja provedena je tematska analiza koju Braun opisuje kao istraživačku metodu za identificiranje, analiziranje i izvješćivanje o obrascima/temama koje se pojavljuju unutar određenih podataka. ${ }^{29}$ Ovom smo analizom induktivnim putem organizirali i opisivali područja vrednovanja knjižnica, kao i stanja knjižničnih resursa visokih učilišta kako su ih procijenila stručna povjerenstva. Tematska analiza podrazumijeva kontinuirano iščitavanje podataka te vraćanje na njih kako bi se što preciznije dijagnosticirale latentne teme. Stručna povjerenstva procjenjuju kvalitetu knjižničnih resursa na osnovi usporedbe svojih dotadašnjih iskustava u korištenju visokoškolskih knjižnica s informiranošću i posjetom knjižnici visokog učilišta koje vrednuju. Iako su podaci na osnovi kojih visoko učilište samovrednuje svoje knjižnične resurse zadani uputama za samoanalizu, sama struktura sadržaja komentara u izvješćima reakreditacijskih povjerenstava nije posebno definirana.

Istraživački korpus temeljio se na 107 izvješća o reakreditaciji koja su javno dostupna na mrežnim stranicama AZVO-a. ${ }^{30}$ Istraživanje se temeljilo na sljedećim fazama: na samom početku istraživanja, bilo je potrebno unutar izvješća izdvojiti

28 Morić Filipović Ivana; Martina Dragija Ivanović. Vrednovanje utjecaja sveučilišnih knjižnica u Hrvatskoj : istraživanje utjecaja zbirki i usluga sveučilišnih knjižnica na akademski uspjeh studenata. // Vjesnik bibliotekara Hrvatske 54, 4(2012), 1-22.

29 Braun, Virginia; Victoria Clarke. Using thematic analysis in psychology. // Qualitative Research in Psychology 3, 2(2006), 79-81.

30 Akreditacijske preporuke. Nav. dj. 
opise stanja knjižnica s obzirom na naša istraživačka pitanja, a potom bilježiti svoje opaske i dojmove o njima. U sljedećem smo koraku, počevši s ponovnim iščitavanjem podataka, opaski i dojmova, sažimali iskaze stručnih povjerenstava kako bismo utvrdili zajedničke teme. Postupkom kodiranja pridodali smo značenje tim sadržajima, gdje kodovi opisuju sadržaj izjave na apstraktnijoj razini, a služe boljem razumijevanju i tumačenju komentara stručnih povjerenstava o stanju knjižničnih resursa visokih učilišta. Nakon toga, u idućoj fazi, pristupili smo grupiranju sadržajno sličnih i srodnih kodova na još višoj razini apstrakcije - definiranju kategorija koje nam služe za odgovaranje na istraživačko pitanje. U pretposljednjem koraku dobivene smo kategorije okupili u zajednička područja višeg reda apstrakcije, odnosno teme. Na koncu smo svako visoko učilište označili šifrom kako ih se ne bi moglo identificirati. Visoke škole označene su šifrom VŠ, veleučilišta šifrom VE, a sveučilišne sastavnice i cjelovita sveučilišta šifrom SV. Također su iz teksta članka izbačene sve informacije pomoću kojih bi se moglo prepoznati visoko učilište.

\subsection{Rezultati i rasprava}

Cilj studije bio je ispitati pomoću kojih su tema vrednovane knjižnice visokih učilišta, a onda se osvrnuti na stanje kvalitete knjižničnih resursa kako su izvijestila stručna povjerenstva za reakreditaciju visokih učilišta. Analizom empirijske građe na spomenuti način došlo se do sedam tema poredanih po broju nađenih komentara:

- relevantnost knjižničnog fonda (79 komentara $\left.{ }^{31}\right)$

- adekvatnost fizičkog prostora (54 komentara)

- jednostavnost pristupa knjižničnim resursima (48 komentara)

- opći dojam o kvaliteti knjižnice (15 komentara)

- brojnost i vještine osoblja (12 komentara)

- adekvatnost financija (7 komentara) $\mathrm{i}$

- korištenje knjižničnih resursa drugih ustanova (7 komentara).

Možemo primijetiti da je velika većina dobivenih tema očekivana budući da se tiču osnovnih preduvjeta za poslovanje knjižnica kako propisuje Zakon o knjižnicama (fond, prostor i oprema, osoblje i financije) te da se mogu naći u teoriji kvalitete knjižnične usluge (izvori informacija, jednostavnost pristupa, adekvatnost prostora i vještine osoblja). Komentarima najbrojnije teme tiču se knjižničnog fonda, fizičkog prostora i jednostavnosti pristupa resursima visokoškolskih knjiž-

31 Dalje će se u tekstu u zagradama navoditi broj pronađenih komentara na naznačenu temu, budući da će se prikazati samo jedan njihov dio. 
nica, pa zato njih možemo izdvojiti kao najvažnija područja procjene kvalitete knjižnica iz perspektive stručnih povjerenstva. Zajedno s knjižničnim osobljem, to su očekivane dimenzije kvalitete knjižnične usluge prema autorima LibQUAL-a - prostor knjižnice i informacijska kontrola. Jedina neočekivana tema koja se javila u ovoj analizi jest korištenje knjižničnih resursa drugih ustanova. Iako su visoka učilišta prema Zakonu o knjižnicama dužna ustanoviti i razvijati knjižnice u svom sastavu, čini se da neka visoka učilišta, koja nemaju svoju knjižnicu ili procjenjuju da njihovi knjižnični resursi nisu dostatni za informacijske potrebe svojih djelatnika i studenata, biraju osigurati svojim studentima pristup knjižničnim resursima drugih visokih učilišta ili ustanova putem ugovora o suradnji. Tako i dokument Strategija razvoja sveučilišnih knjižničnih sustava u Republici Hrvatskoj : 2013.- 2015. ${ }^{32}$ predviđa mogućnost da visoka učilišta koja nemaju vlastitu knjižnicu, a koja sklope ugovor o suradnji sa sveučilišnom knjižnicom i/ ili knjižnicom sastavnicom sveučilišta, mogu biti članice sveučilišnog knjižničnog sustava. U nastavku ćemo pobliže opisati i analizirati svaku od tema.

\section{1) Relevantnost knjižničnog fonda}

Komentarima najbrojnija tema kvalitete knjižnice iz perspektive stručnih povjerenstava jest procjena relevantnosti knjižničnog fonda. Budući da je osnovna uloga visokoškolskih knjižnica ,odabiranje, nabavljanje, organizacija, osiguravanje pristupa i čuvanje knjižnične zbirke ${ }^{\text {“33 }}$ kako bi pružile neposrednu podršku obrazovnom, znanstvenom, ali i javnom djelovanju djelatnika i studenata visokog učilišta, ne iznenađuje da se tema relevantnosti knjižničnog fonda pojavila u mnogobrojnim komentarima. Bogatstvo fonda odlikuje se raznovrsnošću naslova i formata te adekvatnošću broja primjeraka publikacija s obzirom na broj i informacijske potrebe korisnika, bez obzira na to odnose li se potrebe na učenje, pripremu ispita, nastavu i/ili znanstveni rad u području i polju djelovanja visokog učilišta. Komentare stručnih povjerenstava na račun kvalitete knjižničnog fonda visokih učilišta grupirali smo u dvije velike kategorije: opremljenost znanstveno-obrazovnim publikacijama (50) i dostupnost elektroničkih izvora (29). Nadalje, prvom kategorijom kojom se utvrđivala kvaliteta tiskanog dijela knjižničnog fonda okupili smo komentare sljedećim kodovima: raznovrsnost $i$ brojnost naslova i primjeraka publikacija (21), suvremenost publikacija (10), opremljenost relevantnim časopisima (6), opremljenost međunarodnim časopisima (5), cjelovi-

32 Strategija razvoja sveučilišnih knjižničnih sustava u Republici Hrvatskoj : 2013.- 2015. Str. 2. [citirano: 2017-05-05]. Dostupno na http://www.nsk.hr/wp-content/uploads/2012/12/Strategija-SKS_web.pdf.

33 Moran, Barbara B.; Elisabeth Leonard. Academic librarianship. // Encyclopedia of library and information sciences. 3rd ed. Boca Raton, FL : CRC Press, 2010. Vol. 1, Academic-Catalogs. 2010. Str. 1. 
tost tekućeg godišta časopisa (4) i zastupljenost publikacija na engleskom jeziku (4). Opisujući opremljenost visokoškolskih knjižnica tiskanom građom, stručna povjerenstva većinom su komentirala siromaštvo i skromnost knjižničnih fondova po pitanju raznovrsnosti i broja naslova i primjeraka građe, kako knjižnica veleučilišta i visokih škola

„(...) knjižnica raspolaže vrlo skromnim knjižničnim fondom s obzirom na vrstu i veličinu institucije." VE10

„Usprkos mogućnosti međuknjižničnog posuđivanja, ponuda naslova ne doseže očekivanu razinu raznovrsnosti i kvantitete..." (VŠ12)

tako i knjižnica sveučilišnih sastavnica (npr. „,... nema puno primjeraka glavnih udžbenika koji se koriste u nastavi." SV02) i

„Visoko učilište bi trebalo imati $20 \%$ obavezne literature raspoloživo studentima u knjižnom fondu, ali čak po vlastitim internim pravilima određeno je samo 5\%.“ (SV08)

Tek mali broj komentara hvali knjižnični fond:

„Knjižni fond je odgovarajući.“VŠ20

„Knjižnica raspolaže potrebnom literaturom na hrvatskom i stranim jezicima, a postoji i sustav međuknjižnične posudbe." SV68

Sljedeći kod koji je apstrahiran tematskom analizom opremljenosti znanstveno-obrazovnim publikacijama jest suvremenost građe. Suvremenost građe neophodna je kako bi korisnici visokoškolskih knjižnica ostali ukorak s razvojem znanosti i znanstvenom produkcijom u polju i području njihova interesa. Većina komentara stručnih povjerenstava izvještava o zastarjelosti publikacija bez obzira na vrstu visokog učilišta. Kada naprimjer komentiraju knjižnice veleučilišta ili visokih škola, primjedbe su sljedeće:

„Manjak suvremene literature u knjižnici, kao i materijala za učenje na mrežnim stranicama Veleučilišta. "VE03

„Što se tiče knjižnice, Povjerenstvo je primijetilo kako su strani naslovi iz knjižničnog fonda zastarjeli. Hrvatski naslovi dostupni su studentima, no strani udžbenici dostupni studentima izdani su prije više od deset godina." VŠn66

Slični su i komentari upućeni knjižnicama sveučilišnih sastavnica:

„... knjižnica je u vrlo lošem stanju (ocjena 1), budući da raspolaže nedovoljnim brojem modernih udžbenika i monografija." SV09 
„Akademska, odnosno znanstvena knjižnica ne posjeduje recentnu literaturu...."SV61

Tek manji broj bilješki pozitivno izvješćuje o suvremenosti knjižničnog fonda, a svi opisuju knjižnice sveučilišnih sastavnica:

„Knjižnica je dobro opremljena najnovijom građom (...)“ SV30

„Knjižnica je dobro opremljena suvremenim materijalima (...)“ SV66

Stručna povjerenstva poseban su naglasak stavila i na vrednovanje znanstvenih i stručnih časopisa u knjižničnom fondu visokih učilišta, što je za očekivati s obzirom na to da je časopis najvažniji medij formalne znanstvene komunikacije. Opaske stručnih komisija govore o nedostatnoj opremljenosti časopisima općenito. Budući da ovdje stručna povjerenstva nisu posebno istaknula format časopisa, pretpostavljamo da su u pitanju tiskani časopisi, jer su komentirajući elektroničke časopise eksplicitno naveli njihov format. Negativni komentari većinom idu na račun knjižnica veleučilišta i visokih škola:

„Povjerenstvo je bilo pomalo iznenađeno nedostatkom (...) znanstvenih ili tehničkih časopisa za svaki od različitih studijski programa."VE04

„Znanstveni časopisi u njoj nisu dostupni (...)“ VŠ02

Jedna je kritika pak išla i na račun knjižnice sveučilišne sastavnice „Knjižnici treba mnogo bolji pristup časopisima (...)"SV61

Ipak dvije bilješke govore o dobroj opremljenosti časopisima, i to samo knjižnica sveučilišnih sastavnica:

„Većina relevantnih časopisa je dostupna." SV34

„Knjižnica ima dobru kolekciju (...) časopisa (...)“ SV39

U vrednovanju časopisa posebno mjesto zauzimaju međunarodni časopisi. Uz pomoć njih znanstveno-nastavno osoblje i studenti dobivaju uvid u svjetski relevantne akademske teme i rasprave. Zastupljenost međunarodnih časopisa sljedeći je aspekt kvalitete znanstveno-obrazovnih publikacija knjižnice. I ovdje se može reći da većina komentara govori o slaboj opskrbljenosti međunarodnim časopisima. To vidimo u komentarima upućenim knjižnicama visokih škola i veleučilišta, kao što su sljedeći:

„Veleučilište ne prima nijedan inozemni časopis, koji bi okvirno pokrio područja studijskih programa (poduzetništvo prehrana, poljoprivreda), što bi u bliskoj budućnosti trebalo svakako provesti.“"VE12 i

„Knjižnica raspolaže s vrlo malo međunarodnih časopisa. Nadalje, knjižnica nije pretplaćena na neke relevantne strane časopise."VŠ06, 
ali i knjižnicama sveučilišnih sastavnica, poput sljedećih:

„Knjižnica u ovom trenutku nije preplaćena na važne međunarodne časopise." SV02

„(...) ona (knjižnica) u svom fondu nema dovoljan broj (međunarodnih) (...) časopisa." SV69

Tek jedan komentar hvali broj međunarodnih časopisa u knjižnici sveučilišne sastavnice:

„Broj ... te posebno stranih časopisa odgovara statusu knjižnice ka[o] vodeće u agronomskoj profesiji.“ SV43

Idući aspekt kvalitete tiskanog knjižničnog fonda također se tiče časopisa, a to je cjelovitost godišta tekućih časopisa. Cjelovitost godišta od posebne je važnosti budući da omogućuje uvid u cjelokupnu znanstvenu produkciju relevantnih časopisa. Svi postojeći komentari naglasili su problem nepotpunih nizova tekućih časopisa, a kao glavni uzrok izdvajaju smanjena proračunska sredstva od strane resornog ministarstva, većinom u knjižnicama sveučilišnih sastavnica:

„Neki svesci ili brojevi časopisa nisu nabavljeni, najvjerojatnije zbog smanjenja financijskih sredstava, što je rezultiralo nepotpunim kolekcijama."SV34

„Zbog rezanja sredstava pojedinim časopisima je prekinuta pretplata 2010. godine, što je dovelo do rupa u zbirci." SV59,

dok jedan komentar ide na račun knjižnice više škole:

„(..) a zbirke časopisa uglavnom nisu potpune - većina pretplata je otkazana nakon nekoliko godina." VŠ06

Zadnji kod kojim smo grupirali komentare o opremljenosti znanstveno-obrazovnim publikacijama jest zastupljenost građe na engleskom jeziku. Engleski je jezik lingua franca u suvremenoj znanstvenoj komunikaciji, pa je građa na tom jeziku neophodna kako znanstveno-nastavnom osoblju tako i studentima, kako bi ostali ukorak s razvojem znanosti. Svi komentari stručnih povjerenstava na tu temu spominju nedovoljan broj građe na engleskom jeziku u knjižnici visoke škole:

„Nema ni mnogo knjiga na engleskom jeziku, iako je to jezik na kojem je napisan velik dio znanstvene literature tog područja." VŠno6,

a onda i u knjižnicama sveučilišnih sastavnica, npr.

„Općenito, na raspolaganju je premalo knjiga na engleskom jeziku...“ SV02 
„Kvalitetu studentskog standarda potvrdili su i strani studenti s kojima je povjerenstvo razgovaralo, koji borave na fakultetu u okviru različitih projekata, ali koji su upozorili na nedostatnost literature na engleskom jeziku u fakultetskoj knjižnici." SV07

Druga velika kategorija teme relevantnosti knjižničnog fonda jest procjena dostupnosti elektroničkih izvora. Pojavom interneta te razvojem informacijsko-komunikacijskih tehnologija, u visokoškolskim knjižnicama elektronička građa postaje ne samo paritetna tiskanom fondu već možda i zauzima primat u zadovoljavanju informacijskih potreba svojih korisnika. Brza, recentna i pouzdana znanstvena informacija ono je što svaka visokoškolska knjižnica želi pružiti svojim korisnicima. Najčešći elektronički izvori koje hrvatske visokoškolske knjižnice osiguravaju svojim korisnicima jesu zbirke elektroničkih časopisa, baze podataka cjelovitih tekstova ili agregatori te citatne i bibliografske baze podataka. Procjena dostupnosti elektroničkih izvora prikazana je pomoću sljedećih kodova: adekvatnost raspoloživih elektroničkih izvora (16), osiguravanje pristupa elektroničkim izvorima uopće (8) i postojanje samostalne pretplate na elektroničke izvore (5).

Aspekt kvalitete dostupnosti elektroničkih izvora koji prvo iznosimo jest osiguravanje pristupa elektroničkim izvorima uopće. On se našao samo u komentarima knjižnica veleučilišta i visokih škola. Većina opaski govori o neosiguravanju pristupa elektroničkim izvorima:

„Studenti i nastavnici nisu u mogućnosti baviti se znanstvenim radom u knjižnici, jer ... nema pristup elektronskim bazama podataka koje sadrže znanstvene ili stručne časopise ili statistike." VŠ03

„Nije osiguran pristup bibliografskim, odnosno elektronskim bazama specijalizirane literature niti specijaliziranim elektronskim tražilicama, (...)“ VŠ06

Manji broj komentara govori o tome da neke veleučilišne knjižnice i knjižnice visokih škola ipak omogućuju pristup elektroničkim izvorima, bilo besplatnim ili komercijalnim bazama podataka:

„Knjižnica sadrži opću građu, a omogućen je i elektronički pristup nizu e-knjiga i sustava." VE06

„Knjižnica također ima pristup bazama podataka s besplatnim materijalima, knjigama i časopisima: World Digital Library, Europeana, EconPapers, besplatne knjige iz područja ekonomije, SocialScience Research Network i Internet Archive." VŠ16

„Studenti imaju uvid u baze podataka (...) koje su među najopsežnijima u svijetu." VŠ2 1 
Drugi, najbrojniji, aspekt kvalitete dostupnosti elektroničkih izvora jest adekvatnost raspoloživih elektroničkih izvora, i to s obzirom na znanstveno polje i područje studija kojima su visokoškolske knjižnice obrazovna, znanstvena i druga podrška. Stručna povjerenstva većinom su izvještavala o nedovoljnoj prikladnosti elektroničkih izvora, a svi komentari tiču se knjižnica sveučilišnih sastavnica:

„Knjižnični resursi su iznimno manjkavi, (...) što zajedno s nedostatkom pristupa elektroničkim časopisima sprječava daljnji napredak u ovom području.“ SV19

„(...) jedini je problem manjak dostupnih baza podataka za koje je Ministarstvo srezalo sredstva." SV51

„Knjižnica bi trebala osigurati pristup većem broju baza podataka (JStor).“ SV55

Stručna povjerenstva okvalificirala su manjak elektroničkih izvora kao prijetnju kvaliteti rada visokih učilišta:

„Nedostatak e-časopisa mogao bi otežati nastavni i znanstveni rad na višim razinama studija." SV37

„Predstojeći prekid državnog financiranja pretplata na elektroničke časopise Stručno povjerenstvo smatra ozbiljnom prijetnjom Fakultetu.“ SV59

Ipak, manji broj bilješki izvještava o pohvali dostupnih elektroničkih izvora:

„Knjižnica ... raspolaže najvažnijim stručnim časopisima, uglavnom on-line." SV30

„(...) međutim istaknuti da je elektronska dostupnost knjižničnih resursa - putem centraliziranog, nacionalnog licenčnog sustava - izvrsna.“ SV42

„Fakultet osigurava i neke važne elektroničke baze podataka (...)“SV56

Treći, posljednji, aspekt kvalitete dostupnosti elektroničkih izvora jest postojanje samostalne pretplate visokog učilišta na elektroničke izvore. Samostalna pretplata indikator je predanosti visokog učilišta u osiguravanju osnovnih sredstava za rad, kao što su elektronički izvori, svojim studentima i znanstveno-nastavnom osoblju. Komentari su upućeni isključivo na račun knjižnica sveučilišnih sastavnica, a većinom navode nepostojanje samostalne pretplate na elektroničke izvore:

„Fakultet nije pretplaćen ni na kakve baze s cjelovitim člancima ili bibliografske baze; (...)"SV14 
„Odjel nije pretplaćen niti na jedan e-časopis, što predstavlja ozbiljan problem." SV21

„Odjel nije pretplaćen na e-časopise“ SV36

Ipak, osim kritika, među komentarima je nađen manji broj bilješki o postojanju samostalne pretplate na elektroničke izvore:

„Pored baza podataka koje financira Ministarstvo znanosti, obrazovanja i sporta, najveći dio knjižničnog fonda (knjiga, časopisa, on-line baze podataka IEEE Member Digital Library i J-STOR-kolekcija Business I) nabavljen je vlastitim sredstvima." SV07

„Najveći dio knjižničnog fonda (knjiga, časopisa, on-line baza podataka kao što je J-STOR) nabavljeno je vlastitim sredstvima." SV08

\section{2) Adekvatnost fizičkog prostora knjižnice}

Druga tema koja se po brojnosti komentara iskristalizirala analizom izjava stručnih povjerenstava o stanju i kvaliteti knjižničnih resursa jest adekvatnost fizičkog prostora knjižnice. Prostor je neophodan preduvjet poslovanju, pa onda i pružanju usluga knjižnice. Iako se pojavom digitalne građe i mogućnosti pristupanja elektroničkim izvorima s nekog drugog mjesta, a da to nije knjižnica, čini kao da je fizički prostor knjižnice izgubio svoju važnost, on postaje produžetak učionica, važno mjesto grupnog i individualnog rada, učenja i istraživanja svojim korisnicima. ${ }^{34}$ Osim te utilitarne funkcije, korisnicima koji ne stanuju u svom obiteljskom domu knjižnica zamjenjuje dom i susjedstvo, kao mjesto gdje se korisnici osjećaju sigurno. ${ }^{35} \mathrm{U}$ procjeni kvalitete prostora stručna povjerenstva smatrala su relevantnima njegove sljedeće aspekte: veličina knjižnice općenito (26), veličina prostora za rad studenata (18), cjelovitost prostora knjižnice (6) te ugođaj u knjižnici (4).

Najviše komentara povjerenstava o fizičkom prostoru išlo je na račun adekvatnosti veličine knjižnice visokih učilišta. Tako je većina komentara naglašavala da su knjižnice male i neadekvatne s obzirom na broj studenata ili veličinu i broj studijskih programa visokog učilišta. Davali su mnogo sličnih komentara kako o knjižnicama sveučilišnih sastavnica

\footnotetext{
34 Freeman, Geoffrey T. The library as place: changes in learning patterns, collections, technology, and use. // Library as place: rethinking roles, rethinking space. Washington, D.C. : Council on Library and Information Resources, 2005. Str. 2-4 [citirano: 2017-05-15]. Dostupno na https://www.clir.org/pubs/reports/pub129/pub129.pdf .

35 Lincoln, Yvonna S. Nav. dj., str. 8-9.
} 
„S obzirom na veličinu Fakulteta, knjižnica je prilično malena (...)“ SV29

„Sam prostor knjižnice, međutim, premalen je za toliki broj studenata..." SV30

„Nedostaci knjižnice su manjak prostora (...)“SV43

tako i o knjižnicama veleučilišta i visokih škola, npr.

„Uzevši u obzir broj upisanih studenata, veličina knjižnice i čitaonice možda nije posve adekvatna." VE06

„Škola ima knjižnicu manjega prostornog kapaciteta“ VŠ21

Tek dva komentara govore o tome da je knjižnični prostor velik, i to samo za knjižnice visokih škola:

„Prostor je spomenute knjižnice velik (...)“VŠ04

„Knjižnica je velika (...)“ VŠ08

Drugi aspekt koji su stručna povjerenstva izdvojila za vrednovanje fizičkog prostora knjižnice jest veličina prostora za rad studenata. Većim dijelom komentari naglašavaju skučenost i neadekvatnost prostora namijenjenog za učenje studenata u knjižnicama sveučilišnih sastavnica:

„Općenito, čini se da ima premalo ili nimalo mjesta na kojima bi studenti mogli raditi."SV02

„Broj sjedećih mjesta u knjižnici je neodgovarajući s obzirom na broj upisanih studenata." SV08

„(...) čitaonica je premalena u odnosu na ukupan broj studenata..."SV14

„Primjetan je manjak (...) prostora koji bi studenti i nastavnici mogli koristiti za rad i učenje." SV22

Rjeđi su bili komentari na čitaonički prostor knjižnica veleučilišta i visokih škola, a kada su postojali, ukazivali su na manjkavosti, poput sljedećih:

„Uzevši u obzir broj upisanih studenata, veličina (...) čitaonice možda nije posve adekvatna." VE06

„Prostor za (...) grupno učenje vrlo je ograničen.“VŠ02

„Pokraj knjižnice postoji i čitaonica koja je premala“"VŠ18

Od svih komentara samo je jedan dijelom išao u pozitivnom smjeru:

„Čitaonica je dosta mala, ali zadovoljava osnovne potrebe." SV49 
Treći aspekt kvalitete prostora knjižnice koji je prepoznat u komentarima stručnih povjerenstava jest njegova cjelovitost, i to na način da je konstatirana ili kritizirana rascjepkanost ili dislociranost prostora knjižnice, a hvaljena njegova integriranost. Integriranost prostora omogućuje korisnicima lakše i bolje zadovoljavanje njihovih informacijskih potreba. Komentari o rascjepkanosti prostora nađeni su samo kod knjižnica sveučilišnih sastavnica:

„Knjižnični su resursi nedostatni i ne posve učinkovito organizirani. Fakultet, primjerice, ima knjižnice na dvije različite lokacije." SV15

„Sveučilište ima knjižnicu veličine $840 \mathrm{~m} 2$ koja se prostire na dvije lokacije" SV18

„(...) neophodno je reorganizirati i objediniti fragmentirane knjižnične prostore ..."SV20

Pored toga, nađeni su i komentari o dislociranosti knjižnice u odnosu na zgradu visokog učilišta:

„(...) da je knjižnica odvojena od glavne zgrade Veleučilišta (...)“VE03

„Knjižnica je trenutno dislocirana od Fakulteta." SV49

S druge strane, pronašli smo tek jedan pozitivan komentar, i to o cjelovitosti prostora:

„Stručno povjerenstvo je posebno impresionirano jedinstvenom knjižnicom..."SV63

Posljednji, četvrti aspekt prostora knjižnice koji smo pronašli u izvješćima stručnih povjerenstava jest ugođaj u knjižnici. Ovdje su grupirani komentari koji dočaravaju privlačnost prostora $\mathrm{i}$ atmosfere $\mathrm{u}$ knjižnici koja motivira korisnike na rad. Od ukupno četiri komentara, dva kritiziraju neprivlačan i demotivirajući prostor knjižnice:

„Smještena je u podrumu i nema danjeg svjetla, i ne pruža motivirajuću atmosferu." VŠ03

„(...) prostorija namijenjena radu studenata nije nimalo privlačna.“ SV04

Druga dva govore o prostoru knjižnica koje su ostvarile suprotan učinak na stručna povjerenstva:

„Visoko učilište nudi (...) odličnu atmosferu pogodnu za učenje.“ SV63

„Unatoč skučenom prostoru dobiva se dojam o kvalitetnom radnom ambijentu i ugodnom radnom okruženju." SV06 


\section{3) Jednostavnost pristupa knjižničnim resursima}

Sljedeća tema kvalitete visokoškolske knjižnice koja je apstrahirana analizom komentara izjava stručnih povjerenstava tiče se jednostavnosti pristupa knjižničnim resursima. Tom temom grupirani su komentari koji opisuju mogućnost lakog i samostalnog pregledavanja i korištenja svih knjižničnih resursa ili stanje opreme pomoću koje se može pristupiti i/ili koristiti resurse. Ta tema određena je informacijskim potrebama, kako neki autori tvrde, ,netradicionalnog ${ }^{6 / 36}$ korisnika ili ,novog knjižničnog korisnika“. ${ }^{37}$ Prema Hubbard i Walter ${ }^{38}$ „,netradicionalnom korisniku“ potreban je pristup željenim informacijama 24 sata dnevno, odnosno kvalitetan udaljeni pristup knjižničnim izvorima, dok je prema Kyrillidou i Persson ${ }^{39}$ „novi knjižnični korisnik“ onaj koji preferira samostalno pretraživanje informacija pomoću jednostavnih informacijskih alata te koji knjižničnu kontrolu nad resursima i građom vidi kao smetnju svom stvaralaštvu. Polazeći od tih shvaćanja korisnika, temom jednostavnosti pristupa knjižničnim resursima okupili smo komentare u sljedeće kategorije: pristup tiskanom knjižničnom fondu (13), opremljenost informatičkom i drugom tehničkom opremom (13), pristup elektroničkim izvorima (11), opremljenost softverom za knjižnično poslovanje ili mrežnim katalogom (8) i prilagođenost knjižnice studentima s invaliditetom (3).

Prva, komentarima najbrojnija, kategorija jest pristup tiskanom knjižničnom fondu, koja se sastoji od sljedećih kodova: duljina radnog vremena i otvoreni pristup građi. Većina komentara na tu temu govori o kratkom radnom vremenu knjižnica kako veleučilišta i visokih škola

„Produljenjem radnog vremena značajno bi se povećala dostupnost naslova studentima i nastavnicima." VE08

„Knjižnica je otvorena samo od 10 ujutro do 17.30 poslijepodne.“VŠ03

„(...) radno vrijeme knjižnice nisu zadovoljavajući (...)“VŠ13

tako i knjižnica sveučilišnih sastavnica

„Knjižnica ima kratko radno vrijeme (...)“ SV06

„Zanimljiva je činjenica da se studenti nisu žalili na radno vrijeme knjižnice, iako je radno vrijeme prilično kratko i preklapa se s terminima predavanja." SV46

\footnotetext{
36 Hubbard, William J.; Donald E. Walter. Assessing library services with LibQUAL : a case study. // The Southeastern Librarian 53, 1(2005), 52.

37 Kyrillidou, Martha; Ann-Christin Persson. The new library user in Sweden : a LibQUAL+TM study at Lund University. // Performance Measurement and Metrics 7, 1(2006), 46.

38 Hubbard, William J.; Donald E. Walter. Nav. dj., str. 52.

39 Kyrillidou, Martha; Ann-Christin Persson. Nav. dj., str. 47-48.
} 
„Povjerenstvo se slaže s mišljenjem studenata da radno vrijeme knjižnice ne zadovoljava njihove potrebe ..." SV52

„Ipak, studentima bi koristilo da je radno vrijeme knjižnice Sveučilišta dulje."SV72

Tek dva komentara knjižnica sveučilišnih sastavnica utvrdila su cjelodnevno radno vrijeme:

„Taj nedostatak je djelomično kompenziran radnim vremenom knjižnice (od 07.00 do 22.00)." SV07

„Odjel, također, raspolaže s (...) knjižnicom s radnim vremenom od 8 do 20 sati." SV70

Drugi aspekt pristupa tiskanom knjižničnom fondu jest način na koji knjižnica organizira svoju građu, odnosno pitanje omogućuje li svojim studentima otvoreni pristup građi. Jedina dva komentara kritiziraju izostanak otvorenog pristupa građi knjižnica sveučilišnih sastavnica:

„(...) studenti nemaju pristup materijalima pa ih ne mogu slobodno koristiti za učenje(...)“SV14

„Organizacija knjižnice s velikim skladištem i malom količinom studentima odmah dostupnih knjiga nije optimalna." SV48

Druga kategorija jednostavnog pristupa tiče se opremljenosti informatičkom i drugom tehničkom opremom. Ta značajka kvalitete pristupa opisana je putem kodova o brojnosti i razini stanja računala (10) te dostupnosti usluge fotokopiranja u knjižnici (3). Većina je komentara o brojnosti i razini stanja računala negativna, odnosno članovi povjerenstva smatrali su da je premalo računala s obzirom na broj studenata kako na veleučilištima i visokim školama

„Dostupan je tek ograničen prostor i samo dva računala.” VŠ03

„Postoji plan za knjižnicu da se dodatno opremi računalima gdje bi studenti imali pristup određenim bazama podataka, za sada je samo par računala na raspolaganju." VŠ08

tako i u sveučilišnim sastavnicama, npr.

„Ovo je ozbiljno pitanje jer ni u knjižnici ni drugdje na Odjelu nema računala s kojih bi studenti mogli pristupati internetu." SV02,

„U knjižnicama Fakulteta i odsjeka, međutim, nedostaju informatički resursi.“SV15

„Fakultet ima svoju prilično malu knjižnicu sa samo dva računala.“ SV41 
Tek jedan komentar hvali računalnu opremu:

„Knjižnica je opremljena modernom računalnom opremom.“ VŠ21

Dostupnost usluge fotokopiranja u knjižnici utvrđena je u trima bilješkama:

„U njoj (knjižnici) postoje ...skener i fotokopirni uređaj.“ VŠ16

„Prostor knjižnice ... je ... opremljen fotokopirnim strojem i LCD projektorom."VŠ22

„Studentima su na raspolaganju i usluge fotokopiranja..."SV15

Treća kategorija teme jednostavnosti pristupa jest pristup elektroničkim izvorima. Ta kategorija sastoji se od dva aspekta: pristupa elektroničkim izvorima $\mathrm{s}$ drugog mjesta, a da to nije knjižnica (6) te pristupa internetu ili elektroničkim izvorima iz knjižnice (5). Mogućnost pristupa elektroničkim izvorima iz doma ili knjižnice značajno produljuje vrijeme koje studenti mogu iskoristiti za učenje ili istraživanje. Svi komentari tiču se poslovanja knjižnica sveučilišnih sastavnica, a većinom govore o nemogućnosti pristupa elektroničkim izvorima iz doma korisnika:

„Nije omogućen pristup elektroničkim resursima od kuće, što bi moglo pomoći u smanjivanju potreba za ionako ograničenim prostorom."SV10

„(...) ni studenti ni nastavnici ne mogu pristupiti elektroničkim resursima od kuće; (...)"SV14

„Studentima i akademskom osoblju treba osigurati mogućnost pristupanja znanstvenim časopisima od kuće." SV61

Tek dva komentara govore o tome da je moguće pristupiti elektroničkim izvorima s fakulteta ili iz doma:

„Online resursi (baze podataka, elektronički časopisi itd.) dostupni su ... od kuće." SV49

„(...) važnim bazama podataka može se lako pristupiti s Fakulteta ili od kuće." SV68

Drugi aspekt pristupa elektroničkim izvorima jest pristup internetu ili elektroničkim izvorima iz knjižnice. Komentari u kojima se kritizira nepostojanje pristupa internetu tiču se isključivo knjižnica sveučilišnih sastavnica:

„Nema bežičnog interneta, što studentima predstavlja značajan problem." SV02

„Međutim, njezin rad (knjižnice) je trenutno otežan zbog nedostatka pristupa on-line resursima."SV12

„(...) čitaonica nema računala ni mrežni pristup (...)“ SV14. 
Samo se u dvjema bilješkama navodi postojanje takva pristupa, i to u knjižnici veleučilišta

„Knjižnica (...) s mogućnošću pretraživanja kataloga Veleučilišta i ostalih umreženih knjižnica pristupom bazama podataka te s (bežičnim) pristupom internetu." VE11

te knjižnici sveučilišne sastavnice

„Online resursi (baze podataka, elektronički časopisi itd.) dostupni su iz knjižnice (...)“ SV49

Četvrta dimenzija jednostavnosti pristupa kao kvalitete visokoškolske knjižnice jest opremljenost softverom za knjižnično poslovanje, odnosno online knjižničnim katalogom. U pronađenim komentarima ističe se postojanje softvera za knjižnično poslovanje, odnosno mrežnog kataloga, a to se većinom tiče knjižnica visokih škola i veleučilišta

„Instalirana je digitalna knjižnica METELwin koja omogućuje pretraživanje naslova u svim METELwin knjižnicama" VE02

„Knjižnica je umrežena u digitalnu knjižnicu Digitel Metelwin Library.“ VŠ14

„Knjižnica Visoke škole član je elektroničke knjižnice Metelwin preko koje ima pristup 950 vanjskih knjižnica i baza podataka." VŠ16

„(..) kao i knjižnični katalog apliciran kroz knjižničarski programski paket MetelWin."VŠ22,

a manjim dijelom knjižnica sveučilišnih sastavnica, npr.

„Knjižnica je visoko informatizirana (sada se koristi programski paket CROLIST, a u pripremi je novi suvremeni programski paket za visokoškolske knjižnice ALEPH).“ SV05

„Knjižnica je u potpunosti informatizirana, te je korisnicima omogućen online pristup katalogu i pretraživanje." SV07

Tek dva komentara naglašavaju nepostojanje mrežnog kataloga, i to samo $u$ knjižnicama sveučilišnih sastavnica:

„Knjižnica (...) nema katalog na internetu koji bi studenti mogli koristiti. Knjige su samo popisane u jednom word dokumentu i zaposlenici ručno zapisuju tko ih je posudio." SV02

„Katalog knjižničnih resursa još nije digitaliziran.“ SV52

Posljednja, peta kategorija teme jednostavnosti pristupa jest prilagođenost knjižnice studentima s invaliditetom. Sva tri pronađena komentara tiču se isklju- 
čivo knjižnica sveučilišnih sastavnica te govore o tome da spomenute knjižnice ne omogućuju odgovarajući pristup knjižnici svojim studentima s invaliditetom:

„(...) studentima $\mathrm{s}$ invaliditetom nisu osigurani odgovarajući uvjeti.“ SV10

„Fakultet nema podršku za slabovidne studente, poput uređaja i literature u prikladnim oblicima (materijali i softver za slušni pristup informacijama, s tiskanim uputama na brajici)" SV14

„Knjižnica (...) niti omogućava pristup invalidima.“ SV31

\section{4) Opći dojam o kvaliteti knjižnice}

Četvrta tema koja se pojavila u analizi izvješća stručnih komisija jest opći dojam o kvaliteti knjižnice. Tom temom grupirali smo komentare u kojima stručna povjerenstva iznose svoje opće dojmove o kvaliteti knjižnice. Do dojmova su došli usporedbom zatečenog stanja knjižnice predmetnog visokog učilišta sa svojih očekivanjima od usluge visokoškolskih knjižnica. Opći dojam o kvaliteti knjižnice sastoji se od dvije kategorije, a to su razina zadovoljenja standarda usluga visokoškolskih knjižnica (10) te razina zadovoljenja potreba studenata od strane knjižnice (5). Kada je riječ o kategoriji razina zadovoljenja standarda, većina komentara govori o tome da su knjižnični resursi visokog učilišta ispod njima očekivanog i samorazumljivog standarda, kako u slučaju knjižnica veleučilišta i visokih škola

„Knjižnica ne udovoljava minimalnim standardima za znanstveno istraživanje, ali studenti nisu osjećali ovaj nedostatak jer nisu naviknuti na korištenje knjiga kao osnove za istraživanje (zadaci itd.).“ VE02

„Knjižnica je ispod standarda, (kad je riječ o prostoru i opremljenosti literaturom).“ VŠ09

„(..) povjerenstvo smatra da knjižnica ne odgovara standardima,(...)“ VŠ13

tako i u slučaju knjižnica sveučilišnih sastavnica

„Kao što zaposlenici i sami dobro znaju, knjižnica je ispod svih standarda." SV01

„Usluge koje nudi knjižnica nisu u skladu s europskim standardima.“ SV29

S druge strane, našli smo tek nekoliko opaski povjerenstava u kojima su njihovi članovi bili impresionirani razinom dostignute kvalitete knjižnice - jednim veleučilištem 
„(...) knjižnica kao i njoj pridružena studijska učionica, (...) -sve je na razini ako ne i iznad razine međunarodnih standarda." VE11

te dvjema knjižnicama sveučilišnih sastavnica

„Stručno povjerenstvo je posebno impresionirano jedinstvenom knjižnicom (...) Knjižnica je nacionalno, ako ne i međunarodno blago koje zaslužuje svaku moguću podršku.“ SV63

„Knjižnica predstavlja značajan razvojni korak naprijed Fakulteta, i znatno [je] poboljšala okruženje za učenje. Impresivna, suvremena fakultetska knjižnica." SV64

Druga kategorija općeg dojma o kvaliteti knjižnice sastoji se od komentara koji govore o tome zadovoljavaju li knjižnični resursi visokih učilišta informacijske potrebe svojih studenata. Dva povjerenstva izvijestila su o tome da visokoškolske knjižnice ne zadovoljavaju informacijske potrebe svojih korisnika:

„(... Povjerenstvo nije uvjereno da knjižnica uistinu zadovoljava potrebe svih studenata." VE04

„(...) knjižnica ne zadovoljava potrebe studenata Odjela jer nije opremljena literaturom potrebnom za izvođenje studijskog programa." SV18

S druge strane, tri komentara ističu da je usluga knjižnica sveučilišnih sastavnica zadovoljavajuća:

„Središnja knjižnica zadovoljava potrebe Odjela, (...)“ SV37

„Knjižnica je zadovoljavajuća, govorimo li o knjigama i raspoloživom prostoru (...)“ SV51

„Veličina, iskoristivost i raspoloživost knjižnice osigurava zadovoljavajuću podršku studentima." SV56

\section{5) Brojnost i vještine osoblja}

Peta tema kvalitete visokoškolske knjižnice koja je apstrahirana analizom komentara izjava stručnih povjerenstava govori o brojnosti i vještinama osoblja. Dvije su potkategorije te teme: adekvatnost brojnosti osoblja (7) i komunikacijske vještine i kompetencije osoblja (5).

Komentari grupirani oko kategorije adekvatnost brojnosti osoblja knjižnica veleučilišta i visokih škola govore o tome da neke od njih posluju bez zaposlenih stručnjaka na knjižničnim poslovima ili pak o nedovoljnom broju zaposlenih knjižničara:

„U knjižnici bi trebalo zaposliti stručnu osobu, kako bi usluge bile na razini statusa Institucije." VE08 
„S obzirom da ne postoji knjižničar, taj posao obavlja jedan od nastavnika ..."VŠ 18

„Pojedine osobe (5 zaposlenih) pomažu studentima u pretraživanju u knjižnici i u bazama podataka kako bi oni dobili pravovremeno tražene informacije." VŠ21

Komentari o neadekvatnosti brojnosti osoblja knjižnica sveučilišnih sastavnica:

„Samo s 3 zaposlena u knjižnici uslugom se koristi oko 6500 studenta.“ SV05

„Broj (...) knjižničara nije zadovoljavajući (...)“ SV27

„Stručno povjerenstvo je posebno impresionirano jedinstvenom knjižnicom koja nema dovoljno zaposlenika (...)“ SV63

Tek jedan komentar ističe adekvatnu brojnost knjižničnog osoblja:

„Knjižnica Fakulteta je vrlo dobra, (...) s dovoljnim brojem kompetentnog osoblja." SV65

Drugu potkategoriju u okviru ove teme čine komunikacijske vještine i kompetencije osoblja. Većina komentara govori o kvalitetnom, stručnom i predanom knjižničnom osoblju:

„Na sreću, korisnicima je na raspolaganju knjižnični entuzijast koji uspijeva posuđivati knjige iz drugih knjižnica (ali treba računati na vrijeme potrebno za dostavu)." VŠ 12

„Knjižnica je mala, ali kvalitetno ekipirana predanim i obrazovanim osobljem." SV12

„(...) a knjižnično je osoblje vrlo susretljivo.“ SV15

„Osoblje knjižnice je izvrsno i vrlo entuzijastično podupire znanstvena istraživanja." SV28

Tek jedan komentar ističe nekompetentnost knjižničnog osoblja:

„(...) osoblje knjižnice se ne čini dostatno educirano za korištenje znanstvenih baza (...)“ SV46

6) Količina financijskih ulaganja

Šesta tema koja se izdvojila analizom bilješki stručnih povjerenstava o stanju i kvaliteti knjižničnih resursa bila je procjena količine financijskih ulaganja, i to sa samo jednom kategorijom: adekvatnost financijskih ulaganja u nabavu građe $\mathrm{i}$ elektroničkih izvora. Kako se postupkom reakreditacije zapravo vrednuju aktiv- 
nosti visokih učilišta, moglo se očekivati da će se pojaviti i tema kojom se mjeri briga osnivača za održivost i razvoj knjižnice. Veća financijska ulaganja znak su želje osnivača za što kvalitetnijim knjižničnim resursima. Rezultati su pokazali da većina komentara govori o manjkavom financijskom ulaganju kako za veleučilišta i visoke škole

„S obzirom na tri studijska programa iz tri različita znanstvena područja, godišnji proračun od 20.000,00 kuna za nabavu knjiga trebao bi se povećati.“VE08

„(...) bi trebao investirati u kupnju naslova za knjižnicu i eventualno se pretplatiti na elektroničke publikacije." VŠ12

tako i za knjižnice sveučilišnih sastavnica, npr.

„Čini se da knjižnica vrlo dobro funkcionira, ali zbog vrlo niskog proračuna, koji iznosi 10.000 eura godišnje, dosta su ograničeni broj i kvaliteta naslova." SV28

„Knjižnica, (...) ali resursi za pretplatu na časopis itd. čine se ograničenima." SV53

„Knjižnici treba mnogo bolji pristup časopisima i više sredstava za nabavu knjiga (...)“SV61)

Tek jedan komentar sveučilišne sastavnice hvali financijska ulaganja u knjižnični fond:

„Odjel i Sveučilište ulažu znatna sredstva u nabavu znanstvene literature, pretplatu na baze i slično.“SV70

\section{7) Knjižnični resursi drugih ustanova}

Posljednja tema koja se iskristalizirala tematskom analizom izjava stručnih povjerenstava o stanju i kvaliteti knjižničnih resursa bila je procjena knjižničnih resursa drugih ustanova. Ta je tema drukčija od svih ostalih tema budući da se njome ne opisuje stanje knjižničnih resursa visokog učilišta. Grupirali smo komentare koji opisuju alternativu knjižnici visokog učilišta, odnosno knjižnične resurse ustanove $\mathrm{s}$ kojom je reakreditirano visoko učilište potpisalo ugovor o suradnji, bez obzira na to ima li predmetno visoko učilište svoju knjižnicu ili ju nema. Tako su stručna povjerenstva u obilasku nekih visokih škola, veleučilišta i sastavnica sveučilišta utvrdila da predmetno visoko učilište nema svoju knjižnicu, već osigurava svojim studentima knjižnične resurse na način da koriste resurse partnerske organizacije

„Nema računala, nema vlastitih prostorija, knjižnice, studentskog restorana, nisu izrađeni planovi za budućnosti. Visoko učilište većinu toga ostavlja na brigu partnerskoj instituciji - (...)“V VŠ01 
ili da ima ugovor o suradnji sa sveučilišnom knjižnicom, npr.

„Veleučilište nema vlastitu knjižnicu pa studenti ovise o ... sveučilišnoj knjižnici i knjižnicama ostalih visokih učilišta."VE05

„(...) u ovom trenutku nema vlastitu knjižnicu, ali studenti imaju pristup Sveučilišnoj knjižnici. Način na koji studenti ... koriste Knjižnicu je reguliran zajedničkim ugovorom između (...) i Sveučilišne knjižnice.“ VS̆07

„Studenti za svoj rad mogu koristiti infrastrukturu Sveučilišta u (...), no na samom učilištu ne postoji odgovarajuća infrastruktura (laboratoriji, knjižnica).“ SV25

Pored toga, ovdje su okupljeni i komentari koji vrednuju knjižnične resurse ugovornih ustanova ili lokalnih knjižnica s obzirom na potrebe studenata reakreditiranih visokih učilišta. Svi pronađeni komentari izražavaju zabrinutost da takvi resursi nisu odgovarajući s obzirom na informacijske potrebe studenata reakreditiranih visokih učilišta:

„Veleučilište trenutno nema knjižnicu. Iako studenti imaju pristup lokalnoj knjižnici, ne može se očekivati da je to dovoljno za stjecanje odgovarajućeg stručnog ili znanstvenog znanja."VE01

„Povjerenstvo je posjetilo i knjižnicu Instituta (...) u (...) s kojim Visoka poslovna škola surađuje. Međutim, knjižnica ne pruža studentima odgovarajuću podršku. Znanstveni časopisi u njoj nisu dostupni i ne postoji knjižnično osoblje." VŠ02

,(...) ta knjižnica ne zadovoljava potrebe studenata Odjela jer nije opremljena literaturom potrebnom za izvođenje studijskog programa." SV18

\section{Zaključak}

U postupku reakreditacije stručna povjerenstva sastavljena od članova akademske zajednice, profesora i studenata - korisnika visokoškolskih knjižnica vrednuju knjižnične resurse visokih učilišta u kontekstu pomoći studentima u izvršavanju njihovih obveza. Ovo je prvo istraživanje o kvaliteti knjižnične usluge koje se koristi podacima dobivenim u postupku reakreditacije visokih učilišta u Hrvatskoj. Podaci su komentari stručnih povjerenstava o stanju knjižnica sveučilišnih sastavnica, veleučilišta i visokih škola. Za analizu komentara koristila se kvalitativna metodologija - tematska analiza. Ovim istraživanjem željeli smo ispitati koje su to teme pomoću kojih povjerenstva vrednuju knjižnice. Tematskom analizom komentara dobivena su sljedeća tematska područja kvalitete knjižnične usluge: 1) relevantnost tiskanog i elektroničkog knjižničnog fonda, 2) adekvatnost 
veličine i karakteristika fizičkog prostora, 3) jednostavnost pristupa knjižničnoj građi, elektroničkim izvorima i internetu iz knjižnice i doma, 4) opći dojam o kvaliteti knjižnice, 5) adekvatnost brojnosti i kompetencija osoblja, 6) adekvatnost financija te 7) korištenje knjižničnih resursa drugih ustanova. Prvih šest tema bilo je očekivano s obzirom na model LibQUAL, ali i Zakon o knjižnicama, dok je sedma tema predstavljala iznenađenje. Naime pretpostavili smo da će se analizom apstrahirati teme srodne dimenzijama modela kvaliteta knjižnične usluge iz korisničke perspektive LibQUAL: 1) procjene kvalitete prostora knjižnice, 2) osobina knjižničnog osoblja te 3) opsega i pristupa odabranim informacijama, građi i elektroničkim izvorima u knjižnici. Tema adekvatnosti financijskih ulaganja također je očekivana budući da su financijska sredstva za rad knjižnice pokazatelj brige visokog učilišta da svojim zaposlenicima i studentima osigura kvalitetne uvjete za rad. Sukladnost pretpostavljenih dimenzija mjerenja kvalitete knjižnične usluge s dobivenim temama pod ponešto izmijenjenim nazivima u ovoj analizi potvrđuje glavne aspekte kvalitete knjižnične usluge.

Tema dobivena u analizi, a naslovljena ,alternativa knjižnici visokog učilišta“, nije bila očekivana budući da su visoka učilišta prema Zakonu o knjižnicama dužna osnovati i razvijati knjižnicu za svoje korisnike. Međutim u ovom se istraživanju pokazalo da manji broj visokih učilišta, bez obzira na vrstu studija koje organiziraju, nema svoju knjižnicu. Zbog toga visoke škole i veleučilišta osiguravaju svojim studentima pristup knjižničnim resursima drugih visokih učilišta ili ustanova putem ugovora o suradnji, dok s druge strane sveučilišne sastavnice usmjeravaju svoje studente na korištenje matične sveučilišne knjižnice, u zamjenu za brigu o vlastitim knjižničnim resursima. Ovdje možemo samo izraziti sumnju u to da knjižnični fondovi drugih visokih učilišta i ustanova mogu kvalitetno zadovoljiti specifične informacijske potrebe studenata određenih studijskih programa.

Drugim istraživačkim problemom željela se utvrditi razina kvalitete visokoškolskih knjižnica prema dobivenim temama. Rezultati su pokazali da postoji trend u kojem su stručna povjerenstva u većoj mjeri kritizirala knjižnične resurse komentiranih visokih učilišta. Kritizirane knjižnice okvalificirane su kao neadekvatna podrška studentima za učenje i istraživanje, i to bez obzira na vrstu visokog učilišta u čijem su sastavu. Knjižnice veleučilišta i visokih škola, kao i sveučilišnih sastavnica, okarakterizirane su kao male i s malim prostorom za učenje, navedeno je da rade prekratko, da matično visoko učilište u njih ulaže premalo financijskih sredstava, da imaju premalo računala i premalo stručnog osoblja, da su skromne glede tiskane i elektroničke građe, zastarjele i siromašne publikacijama na engleskom jeziku te relevantnim međunarodnim časopisima, kao i da ne omogućavaju pristup internetu i elektroničkim izvorima iz knjižnice ili doma korisnika.

S druge strane, kada su stručna povjerenstva hvalila knjižnične resurse visokih učilišta, bilo je riječi o impresivnim knjižnicama s jedinstvenim prostorom, odličnom radnom atmosferom, predanim i obrazovanim osobljem, bogatim knjiž- 
ničnim fondom sa suvremenom građom i relevantnim (međunarodnim) časopisima pretraživima u mrežnom katalogu te izvrsnim elektroničkim izvorima kojima njihovi studenti mogu pristupiti iz knjižnice, ali i od kuće. Nažalost, u pitanju je tek mali broj knjižnica, no one svojim poslovanjem pokazuju drugim visokim učilištima na koji bi način trebalo razvijati svoje knjižnične resurse, a sve s ciljem bolje uspješnosti rada svojih studenata i zaposlenika.

Ovo istraživanje ima i nekoliko ograničenja. Poteškoće u analizi predstavljao je neujednačen sadržaj izvještaja stručnih povjerenstava, odnosno činjenica da se nisu sve teme javile kod svih knjižnica - neke su teme bile naglašene, dok se druge nisu javljale često u komentarima. Osim toga, vrednovanje knjižničnih resursa u postupku reakreditacije temeljeno je na procjenama različitih stručnih povjerenstava, pa je za pretpostaviti da su povjerenstva ocjenjivala knjižnice s ne posve ujednačenim kriterijima.

No bez obzira na navedena ograničenja istraživanja, ovi rezultati mogu poslužiti kao dobre praktične smjernice za poboljšanje poslovanja visokoškolskih knjižnica općenito, a posebno u segmentu podrške studentskom učenju i istraživanju. Također, ovo istraživanje daje dosad najpotpuniji uvid u razinu kvalitete hrvatskih visokoškolskih knjižnica općenito, a posebno dosad neispitanih knjižnica veleučilišta i visokih škola.

\section{LITERATURA}

Akreditacijske preporuke [citirano: 2017-05-05]. Dostupno na https://www.azvo.hr/hr/ vrednovanja/postupci-vrednovanja-u-visokom-obrazovanju/akreditacijske-preporuke

Badurina, Boris; Martina Dragija Ivanović; Maja Krtalić. Vrednovanje knjižničnih službi i usluga akademskih i narodnih knjižnica. // Vjesnik bibliotekara Hrvatske 53, 1(2010), 47-63. Dostupno i na http://hrcak.srce.hr/file/120894 [citirano: 2017-0105].

Braun, Virginia; Victoria Clarke. Using thematic analysis in psychology. // Qualitative Research in Psychology 3, 2(2006), 77-101.

Brophy, Peter. The academic library. London : Facet Publishing, 2002.

Cullen, Rowena. Addressing the digital divide. // Online Information Review 25, 5(2001), 311-320.

Čuić, Blaženka. Balanced scorecard kao pomagalo za vrednovanje knjižnice : primjer Knjižnice Filozofskog fakulteta u Osijeku. // Vjesnik bibliotekara Hrvatske 55, 1(2012), 45-64. Dostupno i na http://www.hkdrustvo.hr/datoteke/1380/vbh/ God.55(2012),br.1 [citirano: 2017-01-15]. 
Dukić, Gordana; Sanda Hasenay; Svjetlana Mokriš Marendić. Analiza zadovoljstva korisnika/studenata u knjižnicama Prehrambeno-tehnološkog i Pravnog fakulteta te u Gradskoj i sveučilišnoj knjižnici Osijek. // Vjesnik bibliotekara Hrvatske 52, 1/4(2010), 172-187. Dostupno i na http://hrcak.srce.hr/file/123568 [citirano: 201702-04].

Freeman, Geoffrey T. The library as place: changes in learning patterns, collections, technology, and use. // Library as place: rethinking roles, rethinking space. Washington, D.C. : Council on Library and Information Resources, 2005. Str. 1-9 [citirano: 2017-05-15]. Dostupno na https://www.clir.org/pubs/reports/pub129/pub129.pdf

Hubbard, William J.; Donald E Walter. Assessing library services with LibQUAL : a case study. // The Southeastern Librarian 53, 1(2005), 46-53.

Kyrillidou, Martha; Ann-Christin Persson. The new library user in Sweden : a LibQUAL+TM study at Lund University. // Performance Measurement and Metrics 7, 1(2006), 45-53.

Kyrillidou, Martha; Mark Young. ARL Statistics, 2003-04 : a compilation of statistics from the one hundred and twenty-three members of the Association of Research Libraries. Washington, DC : Association of Research Libraries, 2005.

Lincoln, Yvonna S. Insights into library services and users from qualitative research. // Library \& Information Science Research 24(2002), 3-16.

Moran, Barbara B.; Elisabeth Leonard. Academic librarianship. // Encyclopedia of library and information sciences. 3rd ed. Boca Raton, FL : CRC Press, 2010. Vol. 1, Academic-Catalogs. 2010.

Morić Filipović, Ivana; Martina Dragija Ivanović. Vrednovanje utjecaja sveučilišnih knjižnica u Hrvatskoj : istraživanje utjecaja zbirki i usluga sveučilišnih knjižnica na akademski uspjeh studenata. // Vjesnik bibliotekara Hrvatske 54, 4(2012), 1-22. Dostupno i na http://www.hkdrustvo.hr/datoteke/1295/vbh/God.54(2011),br.4 [citirano: 2017-01-08].

Parasuraman, A.; Valarie A. Zeithaml; Leonard L. Berry. A conceptual model of service quality and its implications for future research. // Journal of Marketing 49, Fall(1985), 41-50.

Petrak, Jelka; Tatjana Aparac Jelušić. Knjižnice na hrvatskim sveučilištima : tradicije i promjene. // Vjesnik bibliotekara Hrvatske 48, 1(2005), 13-30. Dostupno i na http:// www.hkdrustvo.hr/datoteke/139/vbh/God.48(2005),br.1 [citirano: 2017-01-08].

Petr, Kornelija. Uspješnost poslovanja knjižnice Pedagoškog fakulteta u Osijeku : zadovoljstvo korisnika knjižnicom i njezinim uslugama. // Vjesnik bibliotekara Hrvatske 43, 4(2000), 80-90.

Petr Balog, Kornelija; Martina Dragija-Ivanović; Kristina Feldvari. Percepcija kvalitete 'iznutra' : razgovori s ravnateljima narodnih i voditeljima visokoškolskih knjižnica. // Vjesnik bibliotekara Hrvatske 53, 3-4(2010), 1-24. Dostupno i na http://hrcak. srce.hr/file/119730 [citirano: 2017-01-10]. 
Petr Balog, Kornelija; Bernardica Plašćak. Customer satisfaction at the Faculty of Philosophy Library in Osijek, Croatia. // Performance Measurement and Metrics 13, 2(2012), 74-91.

Pikić, Aleksandra. Kvaliteta knjižnične usluge u visokoškolskoj knjižnici iz korisničke perspektive : doktorski rad. Zagreb : A. Pikić, 2015.

Radičević, Vesna. Samovrednovanje visokoškolske knjižnice - na primjeru Knjižnice Filozofskog fakulteta u Osijeku. Knjižničarstvo 17, 1(2013), 83-98. [citirano: 2017-01-12]. Dostupno na http://www.knjiznicarstvo.com.hr/wp-content/uploads/2013/06/210_Radicevic_2013_1.pdf

Skupni katalog Nacionalne i sveučilišne knjižnice i Sveučilišta u Zagrebu [citirano:2017-05-15]. Dostupno na http://skupnikatalog.nsk.hr/

Standardi i smjernice za osiguranje kvalitete u europskom prostoru visokog obrazovanja [citirano: 2017-05-05]. Dostupno na http://www.enqa.eu/indirme/esg/ESG\%20 in $\% 20$ Croatian_by\%20ASHE.pdf

Standardi za visokoškolske knjižnice u Republici Hrvatskoj. // Glasnik Ministarstva prosvjete i kulture Republike Hrvatske 1, 3/4(1991), 19-21.

Strategija razvoja sveučilišnih knjižničnih sustava u Republici Hrvatskoj : 2013.2015. [citirano: 2017-05-05]. Dostupno na http://www.nsk.hr/wp-content/uploads/2012/12/Strategija-SKS_web.pdf

Thompson, Bruce; Martha Kyrillidou; Colleen Cook. On-premises library versus Google-like information gateway usage patterns : a LibQUAL $+\circledR$ study. // portal: Libraries and the Academy 7, 4(2007), 463-480.

Udiljak Bugarinovski, Zrinka. Benchmarking u funkciji unaprjeđenja marketinga u visokoškolskim knjižnicama : specijalistički poslijediplomski rad. Zagreb: Z. Udiljak Bugarinovski, 2011.

Upute za izradu samoanalize veleučilišta i visokih škola. [citirano: 2017-05-05]. Dostupno na https://www.azvo.hr/images/stories/vrednovanja/reakreditacija_vu/ Upute $\% 20$ za\%20sastavljanje\%20samoanalize-visoke $\% 20 \%$ C5\%A1kole-veleu\%C4\%8Dili\%C5\%A1ta\%202013.doc

Upute za izradu samoanalize visokih učilišta u sastavu sveučilišta. [citirano: 201705-05]. Dostupno na https://www.azvo.hr/images/stories/vrednovanja/reakreditacija_vu/Upute\%20za\%20sastavljanje\%20samoanalize-sveu\%C4\%8Dili\%C5\%A1ta-2013.doc

Zakon o knjižnicama. // Narodne novine 105, 1616(1997). [citirano: 2017-05-05]. Dostupno na http://narodne-novine.nn.hr/clanci/sluzbeni/1997_10_105_1616.html 